\title{
Analysis of the Physicochemical Burden of Oyo State Fish Pond, Ibadan, Southwest Nigeria
}

\author{
*11BABATUNDE, BB; WOKE, GN \\ Environmental Biology Unit, Department of Animal and Environmental Biology, Faculty of Science, University of Port Harcourt P.M.B. \\ 5323, Choba. \\ *Correspondence author: bolaji.babatunde@ uniport.edu.ng
}

\begin{abstract}
Physicochemical characteristics of the Oyo State fish pond (OYSFP) was analysed to assess the water quality status in relation to the fish produced in the pond for human consumption. The pond was originally designed to control storm waters from the high lands around but was later converted for the purpose of commercial fish production and other uses by the State Government. The pond is a recipient of tributaries of wastewaters from Premier Hotel (PHWW), Coca Cola bottling plant (CCWW), University of Ibadan Teaching Hospital (UCHWW) and Bodija Residential area (BDJWW). Results of the physico-chemical parameters showed most of the parameters were higher than the maximum permissible limits for surface waters and discharge of wastewaters into surface waters. Premier Hotel wastewater (PHWW) had the lowest $\mathrm{pH}$ value of 6.41 and the most acidic of all the wastewaters sampled. OYSFP recorded the lowest dissolved oxygen value of $2.03 \mathrm{mg} / \mathrm{L}$ and the highest BOD, COD, nitrate, TS and conductivity values of $78.04 \mathrm{mg} / \mathrm{L}, 235.26 \mathrm{mg} / \mathrm{L}, 78$ $\mathrm{mg} / \mathrm{L}, 1428.50,947 \mu \mathrm{S} / \mathrm{cm}$ respectively. The highest sulphate value of $248 \mathrm{mg} / \mathrm{L}$ was recorded for BDJSW, this was probably due to runoffs from vegetable gardens along the stream bearing inorganic fertilizers. Other macroscopic observations showed that PHWW was slimy to touch, fowl smelling, dark in colour and had animal life forms such as maggots and flying insects residing in it. CCWW was brownish in colour and slightly smelly and fishes were sighted. OYSFP was dark, muddy, fowl smelling, the surface was covered by aquatic weeds predominantly water hyacinth. UCHWW was transparent, foamy, slimy, slightly smelly and no animal life was sighted in it. BDJWW was clear, no odour, animal life forms including fish and surface arthropods were sighted. Results of physicochemical parameters reported in the present study indicate contamination in OYSFP and fish produced there may not be suitable for human consumption. (C) JASEM
\end{abstract}

\section{http://dx.doi.org/10.4314/jasem.v19i2.12}

\section{KEY WORDS: fish pond, wastewaters, Physico-chemical analysis}

\section{INTRODUCTION}

Despite the growing concerns for the contamination of surface and ground water, little attention is given to the proper treatment and disposal of human dejects and toxic substances generated by industrial, agricultural activities, health and hospitality services units, which are directly dispensed into channels, reaching natural surface water and contaminating ground water. Apart from the acute toxicity of these chemicals to natural biota, the ecological imbalance created usually results to irreversible levels of community disorderliness.

The Oyo State fish Pond designated for the purpose of this study as (OYSFP) which was originally designed to control storm waters from adjoining highlands has now become useful for other purposes including fish production, agricultural activities, carwash and probably a source of drinking water for inhabitants downstream. Apart from storm waters that enter the OYSFP carrying all sorts of contaminants from the land, there are other sources contributing complex chemicals into the pond, these include; effluents from premier hotel designated as Premier Hotel Waste Water (PHWW), wastewaters from University College Hospital (UCHWW), Coca Cola industrial effluents (CCWW) and households based wastewaters from Bodija residential area (BDJWW). There is however, a general dearth of information on the pysico-chemical composition of the contributors and the pond itself. It is therefore necessary to carryout empirical studies to reveal the physical and chemical status of this waster shed to determine the potential hazard it may constitute to human health through its new uses.

It is expected that OYSFP receiving effluents from different sources should be saturated with complex array of chemicals that may pose a threat to ecologic and human health. The hospital for instance, represent an incontestable release source of many chemical compounds including disinfectants, 
detergents, and diagnostic agents such as X-Ray and antibiotics which are an important group of pharmaceuticals in today's medicine (Giuliani et al.; 1996, Hartmann, 1998). These chemicals represent the complex mixture usually contained in hospital wastewaters which is more often than not released directly into our environment with little or no knowledge whether they may have an impact on the environment and human health (Kümmerer, 2001). Indeed, some of the substances found in hospital wastewaters are genotoxic and are suspected to be a possible cause of the cancers observed in the last decades (Jolibois and Guerbet, 2005).

Hospital wastewaters also contain pathogenic microorganisms, heavy metals, toxic chemicals, radioactive elements and infectious materials containing HIV, Hepatitis virus etc (Lue-Hing et al.,1999) which if left untreated, could lead to outbreaks of communicable and infectious diseases, diarrhoea epidemics, water contamination, radioactive pollution and a host of other ecological and public health complications such as antibiotic resistance among wild pathogens (Guardabassi et al., 1999 and Rhodes et al., 2000) and feminization in fish exposed to $17 \beta$-ethenylestradiol (Jobling et al., 1998; Lange et al., 2001; Routeledge et al., 1998). Non target organisms including man become victims of the salvation others have enjoyed through the health care, save one, kill two.

Ravikant et al., (2006), reported that besides deviations in the physico-chemical parameters such as $\mathrm{pH}$, total suspended solids (TSS), biological oxygen demand (BOD) and chemical oxygen demand (COD), hospital effluents have a high load (0.58 to $40 \%$ ) of multiple drug resistant (MDR) bacteria. Hence, the effluent discharged into the environment can be a grave public health hazard. The MDR bacteria may cause infections in community members and would pose serious therapeutic problem and can be more dangerous if their drug resistance is transferred to other sensitive pathogens in the environment.

Hospitality services like the Premier Hotel and residential areas are capable of contributing a myriad of complex chemicals collectively referred to as Pharmaceuticals and Personal Care Products (PPCPs) resulting from washing, bathing, cleaning, other household conveniences and drugs use and disposal (Daughton and Ternes, 1999). These chemicals which are enjoying free discharge in large quantities into the environment have been reported to cause subtle but significant changes in ecologic and human health even at very low levels (Heberer, 2002; Kolpin et al., 2002; Haggard et al., 2006; Xia et al., 2005). Coca Cola is a beverage factory and its effluents are capable of contributing heavy metals and also cause high Biochemical demand in the receiving water body.

This present study was carried out to determine the physico-chemical burden of the Oyo State Fish Pond and its tributaries as a reconnaissance to further research that is needed to establish the safety of using the pond as surface water serving several ecologic and human needs including fish production.

\section{MATERIALS AND METHODS}

The Oyo State fish pond (OYSFP) is located in Ibadan North local council of Oyo State, Nigeria (N $7^{\circ} 24^{\prime} 17.66$ ", E $3^{\circ} 53$ ' 51.91"Alt: $234 \mathrm{~m}$ ). Figure 1 is the hydrological map of Ibadan North showing the location of the project site. Water samples were collected from the pond and the four major contributors of wastewaters into the pond namely; Premier Hotel wastewaters (PHWW: N 7 24' 31. 18", E $3^{\circ}$ 53' 40.84", Alt.291M), Coca Cola bottling plant wastewaters (CCWW: N $7^{\circ} 24^{\prime} 31.99^{\prime}$, E $3^{\circ} 53^{\prime}$ 53.03", Alt.240M), University of Ibadan Teaching Hospital wastewaters (UCHWW: N $7^{\circ} 24$ ' 25.12", E $3^{\circ} 54^{\prime}$ 04.26"Alt.234M ) and Bodija Residential area wastewaters (BDJWW: N $7^{\circ} 24^{\prime} 34.67^{\prime}$, E $3^{\circ} 54^{\prime}$ 02.98, Alt. 233M ).

Wastewater samples were taken in the month of December 2007 at the above coordinates points. Wastewaters of 40 grab samples of $50 \mathrm{ml}$ each were collected compositely into $2 \mathrm{~L}$ plastic bottles with screw caps. For dissolve oxygen $250 \mathrm{ml}$ dissolve oxygen bottles were used to collect wastewater samples and these were fixed in situ with Winkler's solutions A and B. All wastewater samples were transported the same day on ice chest to analytical laboratory in Chemistry Department, University of Ibadan for analysis of physicochemical parameters.

Conductivity, pH, Total dissolved solids,-TDS and alkalinity were determined In-situ using HANNA and HORIBA U 10 multi-parameter meters with probes calibrated with standard solutions provided. Dissolved Oxygen was determined by Azide modification procedure (APHA-AWWA-WEF 2005). Chemical Oxygen Demand (COD) by Standard dichromate procedure (APHA-AWWA-WEF 2005). Nitrate-Nitrite determination by Cadmium reduction method (APHA-AWWA-WEF 2005). 


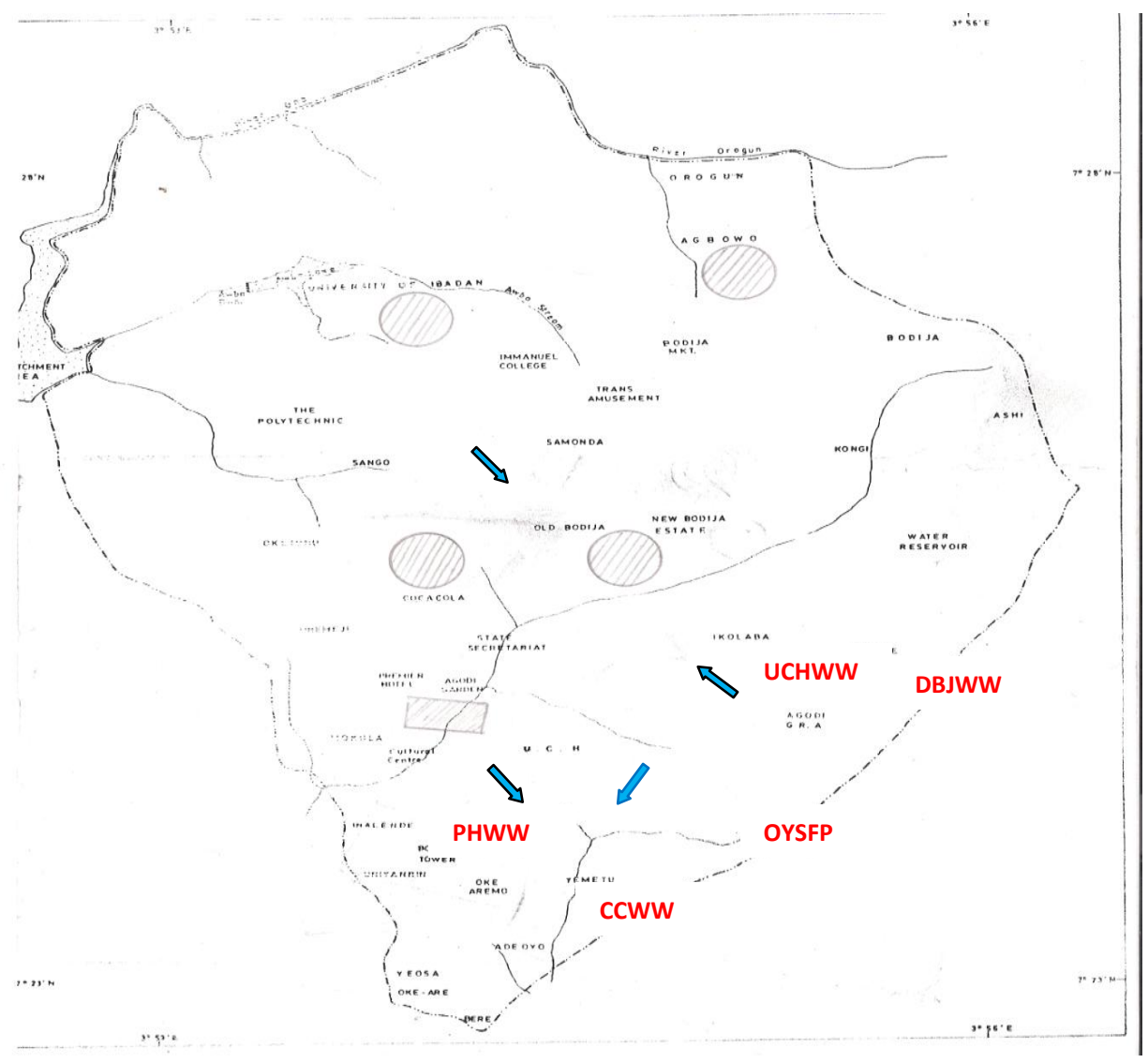

Fig 1: Hydrological map of Ibadan North showing sampling points in RED

\section{RESULTS AND DISCUSSION}

Results of the physico-chemical parameters analysed for the OYSFP and the other contributors of wastewaters into it (PHWW, CCWW, UCHWW and BDJWW) are presented in table 1 and Fig 1 is a comparative representation of some of the parameters. OYSFP showed the highest levels in most of parameters except for dissolved oxygen which was lowest in it Fig 1. PHWW recorded the lowest $\mathrm{pH}$ of 6.41 and the highest $\mathrm{pH}$ value of 7.75 was recorded for BDJWW Table 1. The lowest DO value of $2.03 \mathrm{mg} / \mathrm{L}$ was recorded for OYSFP and the highest DO value of $27.43 \mathrm{mg} / \mathrm{L}$ was recorded for BDJWW Fig 1. PHWW also recorded a very low DO value of $3.05 \mathrm{mg} / \mathrm{L}$ Table 1 and Fig 1. Dissolved oxygen levels in OYSFP and PHWW were below stipulated limits by FEPA, (1991) and WHO, (2006). OYSFP recorded the highest BOD, COD, Nitrate, TS and Conductivity values of $78.04 \mathrm{mg} / \mathrm{L}, 235.26$ $\mathrm{mg} / \mathrm{L}, 78 \mathrm{mg} / \mathrm{L}, 1428.50,947 \mu \mathrm{S} / \mathrm{cm}$ respectively Fig 1. The highest alkalinity value of $120 \mathrm{mg} / \mathrm{L}$ was recorded for PHWW and UCHWW Table 1. Total hardness recorded the highest value of $190 \mathrm{mg} / \mathrm{L}$ for UCHWW which may be due to the presence of cations in such waste streams and the lowest of 90 $\mathrm{mg} / \mathrm{L}$ for PHWW. BDJWW recorded the highest sulphate value of $248 \mathrm{mg} / \mathrm{L}$ which may be attributed to runoffs from farms and OYSFP recorded the lowest sulphate value of $148 \mathrm{mg} / \mathrm{L}$.
The $\mathrm{pH}$ of an aquatic system is an important indicator of water quality and the extent of pollution in the watershed areas. Unpolluted water streams normally have a near neutral or slightly alkaline $\mathrm{pH}$ between 6.5-8.5 as stipulated by (WHO, 2006). The concentration of hydrogen ion has great significance for chemical and biological process occurring in natural water as it can influence the growth of water biota, especially fish population. Also, most of the aquatic organisms are adapted to an average $\mathrm{pH}$ and do not withstand abrupt changes. The $\mathrm{pH}$ value of 6.41 for PHWW is below the stipulated standard of 6.5-8.5 by FEPA, (1991), WHO, (2006). The PH values for all the other stations sampled compared well with the above stipulated standards.

High BOD and Nitrates values in OYSFP were above stipulated standards and may account for the low dissolved oxygen recorded in the pond which can cause anoxic conditions capable of killing living organisms in the pond, fish produced in such a pond may be under oxidative stress and this can affect the flesh quality of the fish for human consumption. High nitrate values in the pond may also have been responsible for the proliferating aquatic weeds in the pond causing eutrophication with its attendant consequences. High nitrates in drinking water may cause oxygen starvation in humans who consume 
such water since nitrates have been reported to interfere with oxygen transportation in the blood.

Although the result of physicochemical characteristics of the UCHWW showed levels within permissible limits, its ecologic and human health effects cannot be conclusive with the present studies as wastewater generated from hospitals are usually loaded with pathogenic microorganisms, pharmaceutical wastes, heavy metals, toxic chemicals, radioactive elements and infectious materials containing HIV, Hepatitis virus etc (LueHing et al. (1999) which if left untreated, could lead to outbreaks of communicable and infectious diseases, diarrhoea epidemics, water contamination, radioactive pollution and a host of other ecological and public health complications such as antibiotic resistance among wild pathogens (Guardabassi et al., 1999). Some of the substances present in hospital wastewaters are genotoxic and are suspected to be a possible cause of the cancers observed in the last decades (Jolibois and Guerbet, 2005). The residues associated with patient excretions may also contain several products with mutagenic activity.

Ortolan and Ayub, (2007), reported the possible presence of cytotoxic (that is, cell direct toxicity) and genotoxic activities in the effluents of a typically large general hospital, in de Porto Alegre, a big southern city of Brazil. Antibiotics which form a good percentage of hospital effluents such as Ofloxacin was found to be genotoxic, and sulfamethoxazole, Ofloxacin and Limcomycin were mutagenic in Ames test and SOS Chromotest (Hartmann et al., 2001). Jos et al., (2003) investigated the potential toxicity and genotoxicity of Pharmaceutically active compounds and reported that they were found to induce chromosomal aberrations in the merismatic cells of Allium cepa and inhibited its root growth and cell division (Monarca et al.,2002). It can be deduced therefore, that using the OYSFP that is receiving wastewater from UCHWW may pose serious health concerns to humans who consume fish produced from the fish pond.

The assessment of the physic-chemical parameters of the OYSFP and its tributaries showed mild contamination and may not be suitable for fish production for human consumption. The water quality especially in the fish pond itself did not compare well with stipulated standards for drinking water by FEPA, (1991) and WHO, (2006) and should not be consumed by humans. More data on heavy metal and other chemical and biological constituents is needed on UCHWW, PHWW, CCWW and flesh quality of the fish produced in this pond for human consumption to adequately inform the public of potential health implication of fish consumed from the OYSFP.

Table 1: Results of the physico-chemical parameters of the wastewaters from the four sampling locations

\begin{tabular}{lllllll}
\hline PARAMETER & BDJWW & UCHWW & PHWW & OYFPWW & CCWW & FEPA \\
\hline Ph & 7.75 & 7.20 & 6.41 & 6.65 & 6.95 & $6.5-8.5$ \\
DO (mg/L) & 27.43 & 5.08 & 3.05 & 2.03 & 12.19 & $>5$ \\
BOD (mg/L) & 38.50 & 48.40 & 62.85 & 78.40 & 13.86 & 15 \\
COD (mg/L) & 117.62 & 147.04 & 191.45 & 235.26 & 44.11 & 50 \\
Alkalinity (mg/L) & 90.00 & 120.00 & 120.00 & 90.00 & 90.00 & 30 \\
T.Hardness (mg/L) & 160.00 & 190.00 & 90.00 & 150.00 & 180.00 & 60 \\
Salinity (mg/L) & 70.00 & 80.00 & 150.00 & 70.00 & 70.00 & 15 \\
Nitrate (mg/L) & 28.00 & 48.00 & 47.00 & 78.00 & 25.00 & 50 \\
Sulphate (mg/L) & 248.00 & 244.00 & 230.00 & 148 & 240.00 & 100 \\
Conductivity $\mu$ sm/cm & 249.00 & 254.00 & 280.00 & 947.00 & 230.99 & 500 \\
T.S.S (mg/L) & 10.50 & 48.00 & 65.03 & 463.00 & 100.03 & 250 \\
T.D.S (mg/L) & 208.00 & 248.00 & 266.50 & 965.50 & 201.50 & 250 \\
T.S (mg/L) & 208.50 & 296.00 & 331.53 & 1428.50 & 201.53 & 500 \\
& & & & & &
\end{tabular}




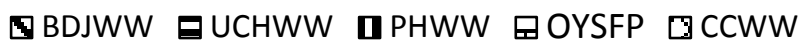

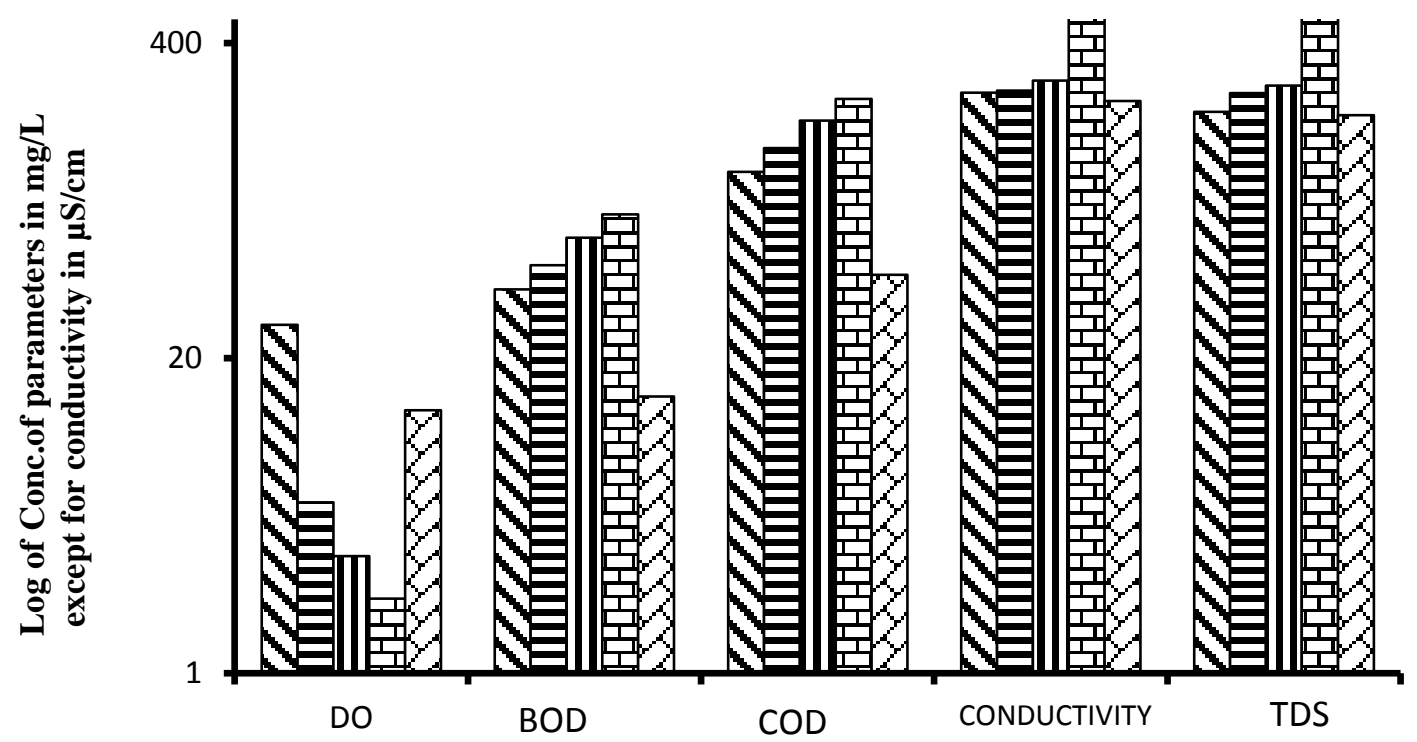

Fig 2: Comparison of the concentrations of various physico-chemical parameters of the sampling points

\section{REFERENCE}

APHA. 2005. Standard methods for the examination of water and wastewater. $18^{\text {th }}$ ed. American Public Health Association, Washington, DC

Daughton, C G and Ternes, T A (1999).

Pharmaceuticals and Personal Care Products in the environment: Agents of subtle change?Environ.HealthPerspect. 107(supplement 6): 907-938.

Federal Environmental Protection Agency (FEPA) (1991). SI8 National Environmental Protection (Effluent limitation) regulation for all categories of industries. FEPA Monograph 2

Giuliani, F., Koller, T., Würgler, F E., Widmer, R M., (1996). Detection of genotoxic activity in native hospital waste water by the umuC Test. Mutation Research. 368, 49-57.

Heberer, T (2002). Occurrence, fate and removal of pharmaceutical residues in the aquatic environment: a review of recent research data. Toxicology letters 131: 5-7

Haggard, B E., Galloway, J.M., Green,W.R, and Meyer, M.T (2006). Pharmaceuticals and other organic chemicals in selected North-Central and Northwestern Arkansas streams. J. Environ. Qual. 35: 1078-1087

Jobling, S., Nolan,M., Tyler, C R.,Brighty, G., Sumpter, J P (1998). Wildspread sexual disruption in wild fish. Environmental Science Technology 32:2498

Jolibois, B., Guerbet, M (2005). Hospital Wastewater genotoxicity. Annals of occupational Hygiene Advance Access Published online on September 5, 2005. Annals of Occupational Hygiene doi: 10, 1093/annhyg/mei 051.

Jos, A; Repetto, G; Rios, J C; Hazen,M J; Molero, M.L; der Peso,A; Salguero, M; FernadezFreire,P; Perez-Martin, J.M; Camean, A (2003).Ecotoxicological evaluation of carbamazepine using six different model systems with 18 end points

Kolpin, D.W., Furlong, E T., Meyer, M.T., Thurman, E.M., Zaugg, S.D., Barber, L.B, and Buxon, H.T 2002). pHarmaceuticals, Hormones and other organic wastewater contaminants in U.S. streams, 1999-2000: A national reconnaissance. Environ. Sci. Technol. 36: 1202-1211.

Kummerer, K., 2001. Drugs in the environment: Emission of Drugs, diagnostic aids and disinfectants into wastewater by hospitals in relation to other sources - a review. chemosphere 45, $957-969$.

Lange, R., hutchinson, $\mathrm{T}$ H., Croudace, C.P., Siegmund, F (2001). Effects of the synthetic estrogen 17 alpha-ethinylestradiol on the lifecycle of the fathead minnow (Pimephales promelas). Environ. Toxicol Chem20:1216 
Lue-Hing, C., Zmuda, J T., Sedita, S.J. Taka, P., (1999) Indigenous levels of HIV in wastewater: an empirical estimate and discussion. In HIV in Wastewater, Presence, Survivability, and Risk to Wastewater Treatment Plant Workers. Water Environment Federation, USA.

Monarca,S.; Richardson,S D., Ragazzo,P., Zerbini, I and Alberti, A. (2002). Mutagenic and Disfectantion by-products in surface drinking water disfected with Peracetic acid, Environ. Toxicol. And Chemistry,

Vol. 21(2) pp. 309-318.

Ortolan, Maria da Graça Silva, \& Ayub, Marco Antônio Záchia. (2007). Cytotoxicity and genotoxicity of untreated hospital effluents. Brazilian Archives of Biology and Technology, 50(4), 637-643.

Ravikant, Vikrant Chitnis, S P Jaiswal, D S Chitnis, Kamlakar Vaidya, (2005). Effluent Treatment
Plant: Why and How. Journal of the Academy of Hospital Administration, 14 (1) $1-6$

Rhodes, C., Huys, G., Swings, J., McGann, P., hney, M., Smith, P., Pickup, R.W (2000). Distribution of oxytetracycline resistance plasmids between acromonads in hospital and aquaculture environments. Implications of Tn1721 in deissemination of the tetracycline resistance determinant Tet A. Applied and Environ. Microbiol. 66 (9) 3883-3890

Routledge. E.J., Sheahan. D., Desbrow. C., Brighty G C., Weldock M., Sumpter.J.P (1998). Identification of estrogenic chemicals in STW effluent. 2 In vivo responses in trout and roach. Environ Sci Technol 32: 1559.

Xia. K., Bhandari. A., Das. K.,Pillar.G (2005). Occurrence and fate of pharmaceuticals and personal Care Products(PPCPs) in biosolids. J. Environ Qual 34: 91-104. 